\title{
Cellular transcripts regulated during infections with Highly Pathogenic H5N1 Avian Influenza virus in 3 host systems
}

Vinod RMT Balasubramaniam¹, Sharifah S Hassan ${ }^{1 *}$, Abdul R Omar $^{2}$, Maizan Mohamed $^{3}$, Suriani M Noor ${ }^{3}$, Ramlan Mohamed ${ }^{3}$ and lekhsan Othman ${ }^{1}$

\begin{abstract}
Background: Highly pathogenic Avian Influenza (HPAl) virus is able to infect many hosts and the virus replicates in high levels in the respiratory tract inducing severe lung lesions. The pathogenesis of the disease is actually the outcome of the infection as determined by complex host-virus interactions involving the functional kinetics of large numbers of participating genes. Understanding the genes and proteins involved in host cellular responses are therefore, critical for the elucidation of the mechanisms of infection.
\end{abstract}

Methods: Differentially expressed transcripts regulated in a H5N1 infections of whole lung organ of chicken, invitro chick embryo lung primary cell culture (CeLu) and a continuous Madin Darby Canine Kidney cell line was undertaken. An improved mRNA differential display technique (Gene Fishing ${ }^{\mathrm{TM}}$ ) using annealing control primers that generates reproducible, authentic and long PCR products that are detectable on agarose gels was used for the identification of differentially expressed genes (DEGs). Seven of the genes have been selected for validation using a TaqMan ${ }^{\circledR}$ based real time quantitative PCR assay.

Results: Thirty seven known and unique differentially expressed genes from lungs of chickens, CeLu and MDCK cells were isolated. Among the genes isolated and identified include heat shock proteins, Cyclin D2, Prenyl (decaprenyl) diphosphate synthase, IL-8 and many other unknown genes. The quantitative real time RT-PCR assay data showed that the transcription kinetics of the selected genes were clearly altered during infection by the Highly Pathogenic Avian Influenza virus.

Conclusion: The Gene Fishing ${ }^{\mathrm{TM}}$ technique has allowed for the first time, the isolation and identification of sequences of host cellular genes regulated during $\mathrm{H} 5 \mathrm{~N} 1$ virus infection. In this limited study, the differentially expressed genes in the three host systems were not identical, thus suggesting that their responses to the H5N1 infection may not share similar mechanisms and pathways.

Keywords: Avian Influenza virus mRNA differential display, annealing control primer, hsp60 gene, cyclin D2 gene, Interleukin 8 gene

\section{Background}

Avian Influenza virus (AIV) is a member of the Orthomyxoviridae family of negative-stranded, segmented RNA viruses and represents a particularly attractive model system as viral replication strategies are closely intertwined with normal cellular processes including the

\footnotetext{
* Correspondence: sharifah.syedhassan@med.monash.edu.my 'Infectious Disease Laboratory (MR3), School of Medicine and Health Sciences, Monash University, Sunway Campus, Kuala Lumpur, Malaysia Full list of author information is available at the end of the article
}

host defense and stress pathways [1]. Over the course of evolution, Influenza virus has developed translational control strategies that utilize cap-dependent translation initiation mechanisms. This causes the host-cell proteins to preferentially synthesize viral proteins and prevent the activation of antiviral response. Translational regulation is a critical component of the cellular response to a variety of stimuli, including growth promoting and growth-repressing signals. Similarly, the cellular response to stress, such as viral infection, nutrient

\section{( Biomed Central}


deprivation, accumulation of misfolded proteins and ER stress, and finally heat shock involves translational control mechanisms that function to activate and repress mRNA translation depending on environmental conditions. For example, during Influenza virus infection, there is a dramatic shutoff of cellular protein synthesis and the selective translation of viral mRNAs [1-3]. Concurrently, in heat shock or stressed cells, there is similarly a disruption of 'normal' cellular protein synthesis and a subsequent redirection of translation to heat shock mRNAs [4-6]. This clearly shows that the Influenza virus infections on cells are closely intertwined with normal cellular processes, including host defense and stress pathways.

The widespread distribution of highly pathogenic avian H5N1 Influenza A viruses in wild birds and, in particular, in domestic poultry populations continues to pose a threat to public health. Severe respiratory disease and a high case-fatality rate have become a hallmark of H5N1 infection in humans as well as in other mammalian species [7-10]. To develop efficient therapeutics against this virus, understanding how the virus interacts with the host in natural infection is necessary. Having insights into the host's responses to influenza (H5N1) would help define targets for therapeutic intervention [11].

One way to do this is to elucidate the mechanisms of virus pathogenesis in chickens, however, how host cells interact and the molecular mechanisms underlying the pathophysiologic process of HPAIV infection in chicken is still poorly understood. Still lacking, also, are the first hand information on the molecular changes in the host induced by the virus to promote its replication and also the pathways triggered in the host that result in immunity and or clearance of the viral infection [11]. The outcome of the infection is determined by complex host-virus interactions with a large number of altered transcriptional and translational rates, and functional kinetics of participating genes. An overview of host responses to AIV at transcriptional level in the trachea and lungs induced by H9N2, H3N2 and H1N1 infection have described the involvement of many genes involved in innate immunity, interleukin activity and vesicle trafficking such as endocytosis and phagocytosis during virus entry [12-15].

We undertook the present study as a preliminary work to understand the selective transcriptome which were up regulated and down regulated during the time of infection with 3 different types of hosts i.e. MDCK cells, primary CeLu cells and lung tissues of infected chickens. We employed a new differential display GeneFishing ${ }^{\mathrm{TM}}$ PCR technique to compare the gene expression in normal and infected cells and tissues. This sensitive technique is based on the determination of multiple expression patterns of pre-determined sequences and we also combined it with the use of annealing control primer $(\mathrm{ACP})^{\mathrm{TM}}$ technology in order to provide a primer with annealing specificity to the template, and allow only targeted product to be amplified without any false artifacts [16,17]. The other great advantage of this technique is that the bands can be isolated and the genes cloned in a vector for sequence identification and stored for further use.

\section{Materials and methods \\ Viruses}

Avian Influenza virus, isolate A/chicken/Malaysia/5744/ 2004 H5N1 was provided by Veterinary Research Institute, Ipoh, Perak, Malaysia. This virus was confirmed to be highly pathogenic in chickens via the intra cerebral pathogenicity test (conducted at the OIE, World Avian Influenza Reference Centre of the Australian Animal Health Laboratory, Geelong, Australia). The pathogenicity of the virus was also confirmed by the demonstration of multiple basic amino-acid sequence at the cleavage site of the HA gene. The viruses were initially isolated and passaged in Madin-Darby canine kidney (MDCK) cells. The virus stock was aliquoted, and titrated to determine tissue culture infection dose $50 \%$ $\left(\mathrm{TCID}_{50}\right)$ in MDCK cells. The experiments were carried out in a Bio-safety level 3 (BSL-3) facility at the Veterinary Research Institute, Ipoh, Perak, Malaysia.

\section{Chickens and virus infection}

Six specific pathogen free (SPF) chickens of one-week of age were each infected intranasally with allantoic fluid containing $10^{4}$ EID50/100 $\mu \mathrm{l} \mathrm{H5N1}$ virus. The chickens were kept in an isolator within a BSL-3 facility of the Veterinary Research Institute, Ipoh Malaysia with food and water available ad libitum. The same batch and age-matched control chickens were treated with PBS pH 7.2 used for virus dilution. As this virus is highly pathogenic to chickens, previous studies have shown that the virus was able to kill the chickens within 24-48 hrs post infection, depending on the dose. In this study, however, chickens were euthanized at $32 \mathrm{hrs}$ post infection and the lungs harvested. Both the control and infected chickens were sacrificed at the same time. The lung tissues were kept at $-80^{\circ} \mathrm{C}$ until used for total mRNA extraction. All animal studies were performed according to protocols approved by Animal Ethics committee of the Veterinary Research Institute (VRI) Malaysia, Department of Veterinary Sciences Malaysia.

\section{Cells and virus infection}

Primary chicken embryo lung cells ( $\mathrm{CeLu})$ were prepared from 19-20 day old-embryos of SPF eggs. Cells were seeded at a density of $10^{6} \mathrm{cells} / \mathrm{ml}$ in Dulbecco's Modified Eagle Medium (DMEM; GIBCO), supplemented with 
$10 \%$ fetal bovine serum (FBS; GIBCO), 100 units/ml penicillin (GIBCO), and $100 \mathrm{mg} / \mathrm{ml}$ streptomycin (GIBCO). MDCK (Madin Darby Canine Kidney) cells were also grown as monolayers in Minimum Essential Media (MEM; GIBCO), supplemented with 10\% fetal bovine serum (FBS; GIBCO), and the same concentration of antibiotics as above. Confluent monolayer cells were infected with the isolate A/chicken/Malaysia/5744/2004 $\mathrm{H} 5 \mathrm{~N} 1$ at a multiplicity of infection of 5 . Infected cells showing 5-10\% cytopathic effect (within 32 hours) were harvested control and infected monolayer cells were washed twice with PBS pH 7.2, scraped into a $15 \mathrm{ml}$ conical tube and centrifuged at $1,500 \mathrm{rpm}$ for $15 \mathrm{mins}$. The cell pellets were stored at $-80^{\circ} \mathrm{C}$ or used immediately for total mRNA extractions.

\section{Messenger RNA isolation}

mRNA was extracted from the infected and uninfected or control MDCK and primary CeLu cells, lungs of infected and control chickens using the RNeasy ${ }^{\circledR}$ mini kit (QIAGEN Inc., Valencia, CA), according to the manufacturer's instructions.

\section{cDNA synthesis}

The mRNA extracted was employed for the synthesis of first strand cDNA by reverse transcriptase, as described by Hwang et al., 2003. Reverse transcription was performed for 1.5 hour at $42^{\circ} \mathrm{C}$ in a final reaction volume of $20 \mu \mathrm{l}$ containing $3 \mu \mathrm{g}$ of the purified mRNA, $4 \mu \mathrm{l}$ of $5 \times$ reaction buffer (Promega, Madison, WI), $5 \mu \mathrm{l}$ of deoxyribonucleotide triphosphate (each $2 \mathrm{mmol}$ ), $2 \mu \mathrm{l}$ of $10 \mu \mathrm{mol}$ cDNA synthesis primer deoxythiamine annealing control primer 1 (dT-ACP1; Table 1), $0.5 \mu \mathrm{l}$ of RNasin ${ }^{\circledR}$ RNase Inhibitor (40 U/ $\mu$ l; Promega), and $1 \mu \mathrm{l}$ of Moloney murine leukemia virus reverse transcriptase (200 U/ $\mu \mathrm{l}$; Promega). First-strand cDNA was diluted by the addition of $80 \mu \mathrm{l}$ of ultra-purified water for the GeneFishing ${ }^{\mathrm{TM}} \mathrm{PCR}$, and stored at $-20^{\circ} \mathrm{C}$ until use.

\section{Annealing control primer ${ }^{\mathrm{TM}}$-based GeneFishing ${ }^{\mathrm{TM}}$ PCR}

Differentially expressed genes (DEGs) were screened by the annealing control primer (ACP) ${ }^{\mathrm{TM}}$-based PCR method using the GeneFishing ${ }^{\text {TM }}$ DEG kits (Seegene, Seoul, South Korea) [17]. The GeneFishingTM PCR technique involved an $\mathrm{ACP}{ }^{\mathrm{TM}}$ system that had a unique tripartite structure in that its distinct 3'-end target core sequence and 5'-end nontarget universal sequence portions were separated by a regulator, it used primers that annealed specifically to the template, and it allowed only genuine products to be amplified; this process eliminates false positive results. Second-strand cDNA synthesis and subsequent PCR amplification were conducted in a single tube. Briefly, second-strand cDNA synthesis was conducted at $50^{\circ} \mathrm{C}$ (low stringency) during one cycle of

Table 1 Primer sequence used in CDNA synthesis and ACPTM-based PCR

\begin{tabular}{|c|c|c|}
\hline Use & Primer name & Sequence \\
\hline cDNA synthesis primer & $\mathrm{dT}-\mathrm{ACP} 1$ & 5'-CTGTGAATGCTGCGACTACGATIIIII (T) 18-3' \\
\hline Reverse primer & dT-ACP2 & 5'-CTGTGAATGCTGCGACTACGATIIIII (T) 15-3' \\
\hline Arbitrary primer & ACP1 & 5'-GTCTACCAGGCATTCGCTTCATIIIIGCCATCGACC-3' \\
\hline \multirow[t]{19}{*}{ (Forward primer) } & ACP2 & 5'-GTCTACCAGGCATTCGCTTCATIIIIAGGCGATGCC-3' \\
\hline & ACP3 & 5'-GTCTACCAGGCATTCGCTTCATIIIICCGGAGGATG-3' \\
\hline & ACP4 & 5'-GTCTACCAGGCATTCGCTTCATIIIIGCTGCTCGCG-3' \\
\hline & ACP5 & 5'-GTCTACCAGGCATTCGCTTCATIIIIAGTGCGCTCG-3' \\
\hline & ACP6 & 5'-GTCTACCAGGCATTCGCTTCATIIIIGGCCACATCG-3' \\
\hline & ACP7 & 5'-GTCTACCAGGCATTCGCTTCATIIIICTGCGGATCG-3' \\
\hline & ACP8 & 5'-GTCTACCAGGCATTCGCTTCATIIIIGGTCACGGAG-3' \\
\hline & ACP9 & 5'-GTCTACCAGGCATTCGCTTCATIIIIGATGCCGCTG-3' \\
\hline & ACP10 & 5'-GTCTACCAGGCATTCGCTTCATIIIITGGTCGTGCC-3' \\
\hline & ACP11 & 5'-GTCTACCAGGCATTCGCTTCATIIIICTGCAGGACC-3' \\
\hline & ACP12 & 5'-GTCTACCAGGCATTCGCTTCATIIIIACCGTGGACG-3' \\
\hline & ACP13 & 5'-GTCTACCAGGCATTCGCTTCATIIIIGCTTCACCGC-3' \\
\hline & ACP14 & 5'-GTCTACCAGGCATTCGCTTCATIIIIGCAAGTCGGC-3' \\
\hline & ACP15 & 5'-GTCTACCAGGCATTCGCTTCATIIIICCACCGTGTG-3' \\
\hline & ACP16 & 5'-GTCTACCAGGCATTCGCITCATIIIIGTCGACGGTG-3' \\
\hline & ACP17 & 5'-GTCTACCAGGCATTCGCTTCATIIIICAAGCCCACG-3' \\
\hline & ACP18 & 5'-GTCTACCAGGCATTCGCTTCATIIIICGGAGCATCC-3' \\
\hline & ACP19 & 5'-GTCTACCAGGCATTCGCTTCATIIIITCTGCGAGC-3' \\
\hline & ACP20 & 5'-GTCTACCAGGCATTCGCTTCATIIIIGACGTTGGCG-3' \\
\hline
\end{tabular}


first-stage PCR in a final reaction volume of $49.5 \mu \mathrm{l}$ containing 3-5 $\mu$ l (about $50 \mathrm{ng}$ ) of diluted first-strand cDNA, $5 \mu \mathrm{l}$ of $10 \times$ PCR buffer plus Mg (Roche Applied Science, Mannheim, Germany), $5 \mu$ l of dNTP (each 2 $\mathrm{mM}), 1 \mu \mathrm{l}$ of $10 \mu \mathrm{M} \mathrm{dT}-\mathrm{ACP} 2$, and $1 \mu \mathrm{l}$ of $10 \mu \mathrm{M}$ arbitrary primer preheated to $94^{\circ} \mathrm{C}$ (Table 1 ). The tube containing the reaction mixture was held at $94^{\circ} \mathrm{C}$, while 0.5 $\mu \mathrm{l}$ of Taq DNA Polymerase $(5 \mathrm{U} / \mu \mathrm{l}$; Roche Applied Science) was added to the reaction mixture. The PCR protocol for second-strand synthesis was one cycle at $94^{\circ} \mathrm{C}$ for $1 \mathrm{~min}$, followed by $50^{\circ} \mathrm{C}$ for $3 \mathrm{~min}$, and $72^{\circ} \mathrm{C}$ for $1 \mathrm{~min}$. After the completion of second-strand DNA synthesis, 40 cycles were performed. Each cycle involved denaturation at $94^{\circ} \mathrm{C}$ for $40 \mathrm{~s}$, annealing at $65^{\circ} \mathrm{C}$ for $40 \mathrm{~s}$, extension at $72^{\circ} \mathrm{C}$ for $40 \mathrm{~s}$, and a final extension at $72^{\circ} \mathrm{C}$ to complete the reaction. The amplified PCR products were separated in $1.5-2 \%$ agarose gel stained with ethidium bromide.

\section{Cloning and sequencing}

The differentially expressed bands were extracted from the gel using the QIAquick ${ }^{\circledR}$ Gel extraction kit (QIAGEN Inc., Valencia, CA), and directly cloned into a TOPO TA ${ }^{\circledR}$ cloning vector (Invitrogen) according to the manufacturer's instructions. The cloned plasmids were sequenced with an ABI PRISM ${ }^{\circledR} 3100$ Genetic Analyzer (Applied Biosystems, Foster City, CA). Complete sequences were analyzed by searching for similarities using the Basic Local Alignment Search Tool (BLAST) search program at the National Center for Biotechnology Information GenBank [18].

\section{Quantitative reverse transcription - polymerase chain reaction (qRT-PCR)}

All RT-PCR were set up in 96-well optical plates using $50 \mathrm{ng}$ of extracted uninfected and infected RNA from CeLu, MDCK cell lines and chicken lung tissue, $10 \mu \mathrm{l}$ TaqMan Universal PCR Master Mix (Applied Biosystems, Foster City, CA, USA), and $1 \mu$ l of primers/probe set containing $900 \mathrm{nM}$ of forward and reverse primers and $300 \mathrm{nM}$ probe was added to a final volume of $20 \mu \mathrm{l}$ per reaction. All samples were tested in triplicates. RTPCR program consisted of incubation at $48^{\circ} \mathrm{C}$ for 30 min, and 40 cycles at $95^{\circ} \mathrm{C}$ for $10 \mathrm{~min}, 95^{\circ} \mathrm{C}$ for $15 \mathrm{sec}$, and $60^{\circ} \mathrm{C}$ for $1 \mathrm{~min}$ with the Step One Plus Real-Time PCR System ${ }^{\circledR}$ (Applied Biosystems). A non-template control and an endogenous control (eukaryotic 18s rRNA) were used for the relative quantification. All quantitations (threshold cycle $[\mathrm{CT}]$ values) were normalized to that of $18 \mathrm{~s}$ rRNA to generate $\triangle \mathrm{CT}$, and the difference between the $\Delta \mathrm{CT}$ value of the sample and that of the reference (uninfected sample) was calculated as $\Delta \triangle \mathrm{CT}$. The relative level of gene expression was expressed as $2^{-\Delta \Delta C T}$ [19]. Primers for qRT-PCR were designed using Primer3 software (http://frodo.wi.mit. edu/cgi-bin/primer3/primer3.cgi) with these parameters: amplicon length, 95-100 bp; primer length, 18-27 nucleotides; primer melting temperature, $60-64^{\circ} \mathrm{C}$; primer and amplicon GC content, $20-80 \%$; difference in melting temperature between forward and reverse primers, $1-2^{\circ} \mathrm{C}$. Primers were synthesized by Integrated DNA Technologies (Coralville, IA, USA). Primer information is listed in Table 2 .

\section{Statistical analysis}

Results expressed as $2^{-\Delta \Delta C T}$ were reported as mean standard deviation and analyzed using paired student's t test. $P$ values $<0.05$ were considered statistically significant.

\section{Results}

Cellular transcripts from 3 different host systems regulated during infection with HPAI H5N1

Differentially expressed mRNAs using a combination of 20 arbitrary primers and two anchored oligo (dT)

Table 2 Primers used in real time PCR assays

\begin{tabular}{|c|c|}
\hline $\begin{array}{l}\text { Amplification } \\
\text { target }\end{array}$ & Sequence $\left(5^{\prime}-3^{\prime}\right)$ \\
\hline RTN4 F & TTACAGATTGCACTGCGTC \\
\hline RTN4 R & TGTAACTGCACAAATCTACCCT \\
\hline RTN4 probe & $\begin{array}{l}\text { 6FAM-GCTGCAGTTGTGCAGCAGGGACTGCA-lowa } \\
\text { Black FQ }\end{array}$ \\
\hline L14 F & TCTTCCTTCTCGCCGAAC \\
\hline L14 R & CATCAACCAAAGCCCTGTT \\
\hline L14 probe & $\begin{array}{l}\text { 6FAM-TGGCCGGGTGGCCTACGTCTCCTTT-lowa Black } \\
\text { FQ }\end{array}$ \\
\hline Hsp60 F & CATGGTGTGACCGTAGCAA \\
\hline Hsp60 R & GGCAATAGAGCGTACCAAGA \\
\hline Hsp60 probe & $\begin{array}{l}\text { 6FAM-ACGAAGAGGCTGGGGATGGCACCACT-lowa } \\
\text { Black FQ }\end{array}$ \\
\hline CCND1 F & CAGAGGAGAACAAACAGATCAT \\
\hline CCND1 R & AAATGAACTTCACATCTGTGGC \\
\hline CCND1 probe & $\begin{array}{l}\text { 6FAM-AGCACGCGCAGACCTTCGTAGCGCT-lowa } \\
\text { Black FQ }\end{array}$ \\
\hline CCND2 F & TAAGCTAGCCAGAGTITTCTCA \\
\hline CCND2 R & CATGAAATGAATTTGCACCTCG \\
\hline CCND2 probe & $\begin{array}{l}\text { 6FAM-TGGGCCCCAAGGAGTCCCACGGAAT-lowa } \\
\text { Black FQ }\end{array}$ \\
\hline CCND3 F & AGTCTCCTCCCTTCCCTTT \\
\hline CCND3 R & AGTAGCGATCCAGGTAGTTC \\
\hline CCND3 probe & $\begin{array}{l}\text { 6FAM-AGGAGCAGCGCTGCGAGGAGGAAGT-lowa } \\
\text { Black FQ }\end{array}$ \\
\hline IL-8 F & CACTGTGAAAAATTCAGAAATCATTGTTA \\
\hline IL-8 R & СТTCACCAAATACCTGCACAACCTTC \\
\hline IL-8 probe & $\begin{array}{l}\text { 6FAM-AATGGAAACGAGGTCTGCTTAAACCCCAAG- } \\
\text { lowa Black FQ }\end{array}$ \\
\hline 18s rRNA F & AGCTCGTAGTTGGATTTCTGTTAATAATTTA \\
\hline 18s rRNA R & GCATATGCCTGCTTTAAGCACTCT \\
\hline 18s rRNA probe & 6FAM-TTTCTCAAAGTAAAATTTCA-lowa Black FQ \\
\hline
\end{tabular}


primers (dT-ACP1 and dT-ACP2) of the 3 different types of host systems infected with the H5N1 virus were isolated, cloned and sequenced. For each of the host system, more than 100 transcripts were observed however, only distinct up regulated or down regulated transcripts as observed on the agarose gels were chosen i.e. after exclusion of poor bands and bands which did not show much differences in intensity between the control and infected cells. For the CeLu H5N1 infected cells (Figure 1) 11 distinct bands could be observed, of which 5 of the transcripts are up-regulated and 6 down-regulated. For the MDCK H5N1 infected cells (Figure 2), 12 distinct bands, of which 6 are up regulated and 6 down regulated were isolated. For the lung tissues of chickens infected with $\mathrm{H} 5 \mathrm{~N} 1$ virus (Figure 3), 14 bands that were significantly up-regulated (4 bands) or down-regulated (10 bands) from various annealing control primers were isolated. Using the BLAST database search, the 37 differentially expressed genes were identified i.e. 15 upregulated and 22 down-regulated genes in the samples of infected hosts, compared to the uninfected. The functional roles, sequence similarities and characterization of the differentially expressed transcripts are summarized in Table 3, 4 and 5. BLASTn searches in GenBank revealed that the differentially expressed genes displayed significant similarities with known genes or expressed sequence tags (ESTs).

\section{Quantitative reverse transcription-PCR (qRT-PCR)}

A real-time RT-PCR assay was developed to validate the mRNA differential display expression data based on the use of a TaqMan probe. We have chosen 7 genes (CCND1, CCND2, CCND3, RTN4, L14, Hsp60 and IL8) that were analyzed using qRT-PCR. Initially, we had intended to only measure the relative quantitation of the down regulated CCND2 (from the mRNA differential display results), however, we thought that it would be interesting to investigate whether H5N1 down regulates other cyclin D family (CCND1 and CCND3) as well. For optimal relative quantification of the 7 selected genes, the fold difference of $\Delta C \mathrm{CT}\left(2^{-\Delta \Delta C T} \pm \mathrm{SD}\right)$ between study groups were calculated (uninfected and infected

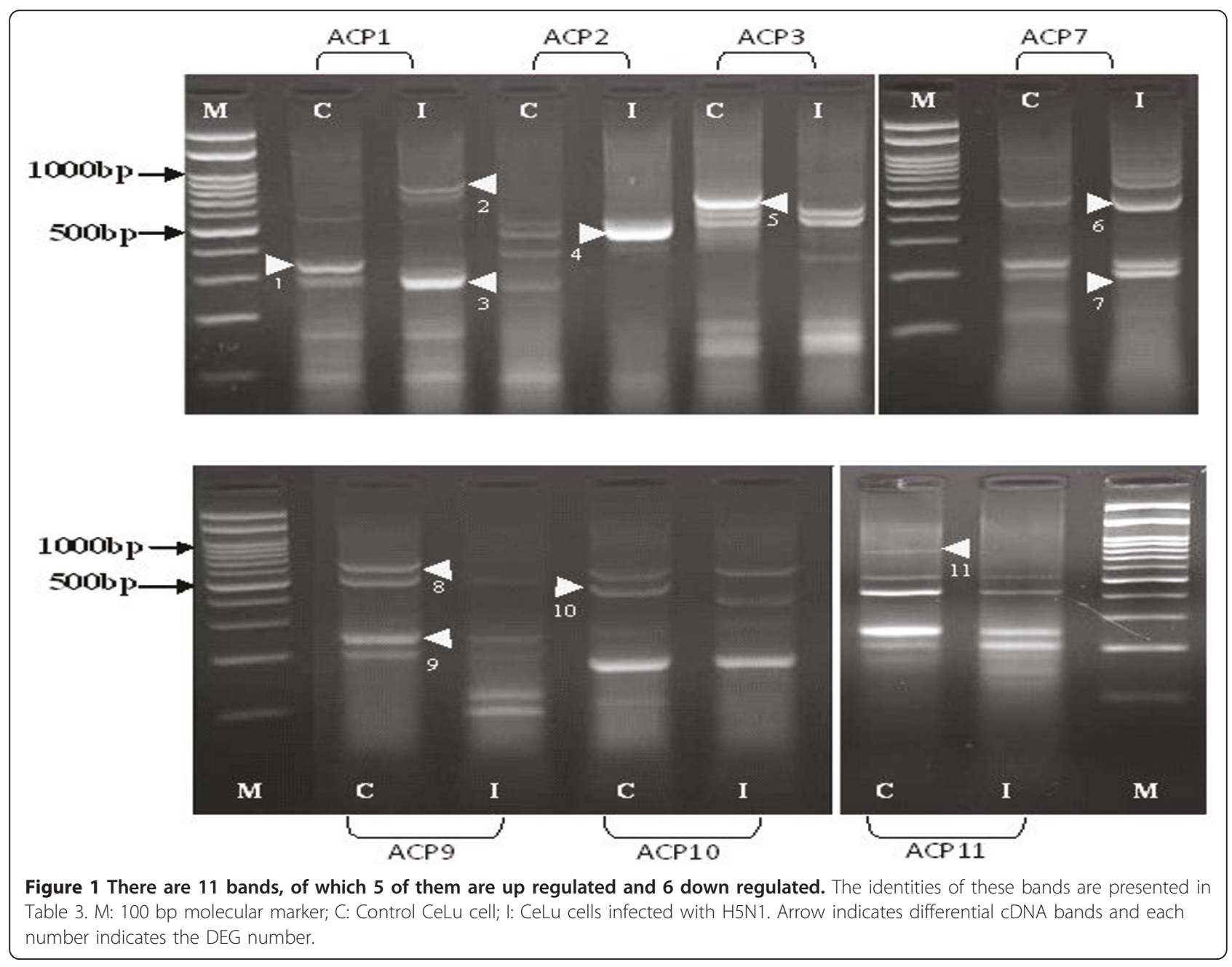




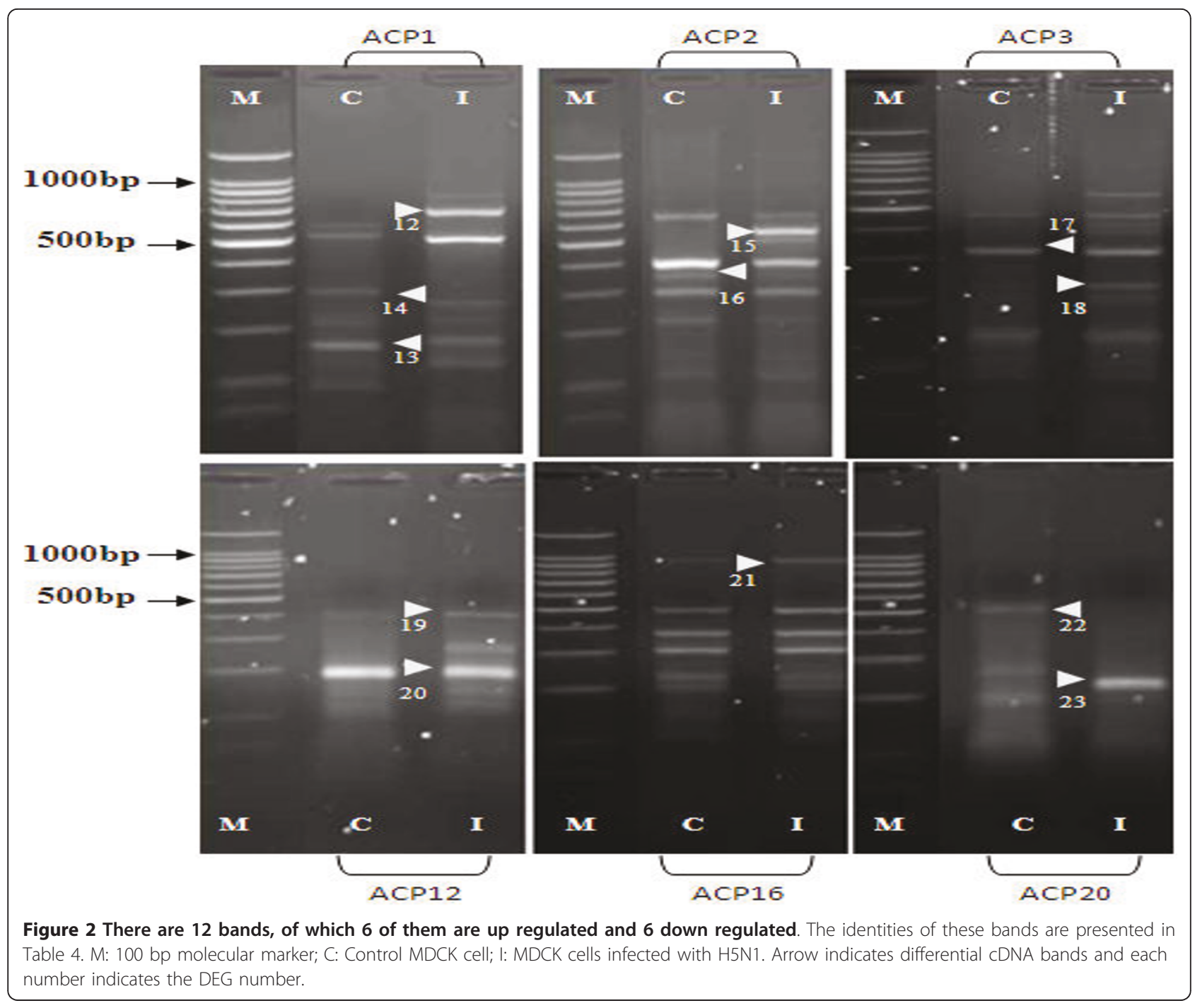

cells). Resulting values were $1.04 \pm 0.02$ for CCND1 gene in uninfected cell, $0.65 \pm 0.09$ for CCND1 gene in infected cell, $1.10 \pm 0.05$ for CCND2 gene in uninfected cell, $0.30 \pm 0.09$ for CCND2 gene in infected cell, $1.37 \pm$ 0.16 for CCND3 gene in uninfected cell, $0.74 \pm 0.14$ for CCND3 gene in infected cell, $1.19 \pm 0.09$ for L14 gene in uninfected cell, $0.17 \pm 0.07$ for L14 gene in infected cell, $1.20 \pm 0.10$ for RTN4 gene in uninfected cell, 0.65 \pm 0.03 for RTN4 gene in infected cell (Figure 4A). These results indicate that there is a significant decrease $(P<0.05)$ in transcription of these 5 genes due to H5N1infection. On the contrary, the resulting values for Hsp60 gene in uninfected cell were $1.00 \pm 0.10,3.78 \pm$ 0.15 for Hsp60 gene in infected cell, $1.00 \pm 0.13$ for IL- 8 gene in uninfected cell and $4.18 \pm 0.12$ for IL- 8 gene in infected cell (Figure 4B). These results indicate that there is significant increase $(P<0.05)$ in transcription of these 2 genes due to $\mathrm{H} 5 \mathrm{~N} 1$ infection.

\section{Discussion}

Difficulty often arises in identifying a gene responsible for a specialized function during a certain biological stage because the gene is expressed at low levels, whereas the bulk of mRNA transcripts within a cell are highly abundant [20]. To screen DEG transcripts in low concentrations while minimizing the false positive results, it was reasonable to use a PCR-based technique. Moreover, it was possible to detect GeneFishing ${ }^{\mathrm{TM}}$ technology reaction products easily on ethidium bromidestained agarose gel. This was supposed to greatly assist studies searching for genes that are expressed differentially in cells under various physiological stages or experimental conditions. In the past, several approaches have been used to compare levels of gene expression, e.g. RT-PCR and northern blot analysis. These approaches were limited to the analysis of one gene at a time, whereas other methods, such as subtractive 


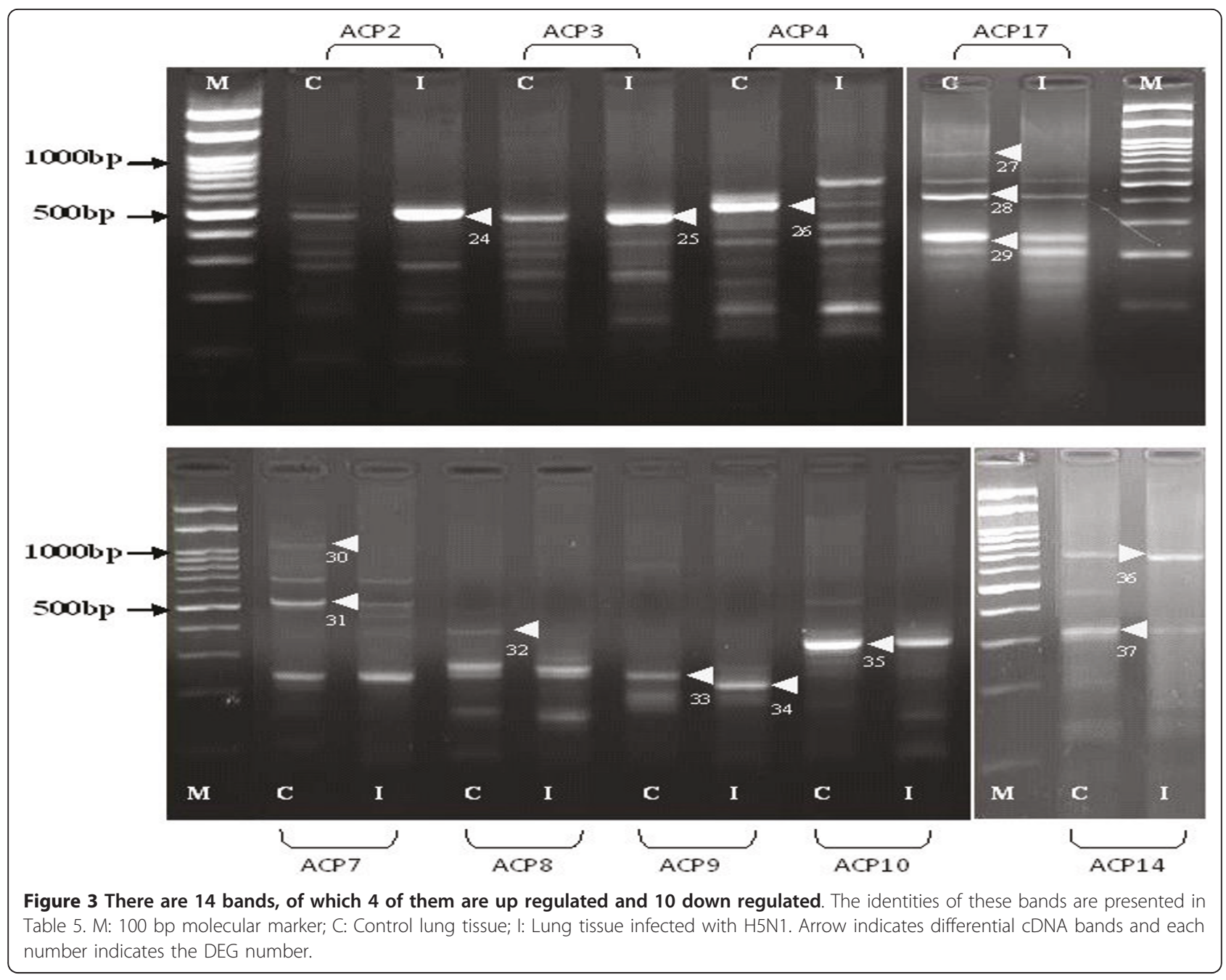

hybridization or variations in the differential display techniques, can determine multiple expression patterns of predetermined sequences; the latter technique is very sensitive, but not quantitative [21]. Large numbers of expressed genes can also be investigated using nucleic acid microarrays. These arrays allow for scanning of large numbers of genes rapidly; however, these techniques have the relative disadvantage of being suitable only for analysis of a fixed number of predetermined gene sequences [22,23].

In this study, mRNA differential display technique was utilized to screen for regulated cellular transcripts during H5N1 infection in 3 different host systems. MDCK cells derived from a continuous (immortal) neoplastic cell line are one of the best mammalian cell models to study the infection of avian influenza virus as it has all the necessary receptors for virus attachment and also can be propagated in large amounts. It is interesting though to compare the responses to the same virus infections of two cell lines, one a continuous mammalian cell line and a primary chicken cell line. Cultured primary CeLu cells provide a more physiologically relevant environment for the molecular target under examination than that same target expressed in an "artificial" immortalized cell environment. This is notably the case with primary chicken embryo lung cells, for which the complex interplay of endogenously expressed ion channels, second messengers and other cell signaling proteins, can be better recapitulated than in transformed immortalized cell lines. It was hypothesized that intact lungs, which are the primary organ for the proliferation of the virus would probably generate some similar DEGs as the CeLu cells due to their similarity in the origin. However, the physiological environment and complex immune interactions of lungs from infected chickens reveal genes that are relevant in a physiological setting involving host responses components to infection. One of these genes is the IL-8. Hundreds of genes (Figures 1, 2 and 3) of the 3 host systems were expressed, out of which 37 DEGs up-and down- 
Table 3 Sequence similarities and characterization of differentially expressed transcripts of Chicken Embryo Lung Cells (CeLu)

\begin{tabular}{|c|c|c|c|c|}
\hline $\begin{array}{l}\text { Clone } \\
\text { Name }\end{array}$ & Identity & $\begin{array}{l}\text { Accession } \\
\text { Number }\end{array}$ & $\begin{array}{l}\text { Homology } \\
(\%)\end{array}$ & Putative functional role \\
\hline$\overline{D E G} 1$ & $\begin{array}{c}\text { PREDICTED: Gallus gallus similar to Prenyl (decaprenyl) } \\
\text { diphosphate synthase, subunit } 2 \text { (LOC421777), mRNA } \\
\text { (down regulated) }\end{array}$ & XM419804 & $96 \%$ & $\begin{array}{l}\text { Catalyzes the formation of all trans-polyprenyl } \\
\text { pyrophosphates from isopentyl diphosphate in the } \\
\text { assembly of polyisoprenoid side chains, the first step in } \\
\text { coenzyme Q biosynthesis. Defects in this gene are a } \\
\text { cause of coenzyme Q10 deficiency. }\end{array}$ \\
\hline DEG 2 & $\begin{array}{l}\text { Dendrobium crumenatum class-1 small heat shock } \\
\text { protein mRNA, partial cds (up regulated) }\end{array}$ & EU302124 & $100 \%$ & $\begin{array}{l}\text { Elevated temperatures or stress induced proteins, in } \\
\text { which its expression is transcriptionally controlled. }\end{array}$ \\
\hline DEG 3 & $\begin{array}{c}\text { Clonorchis sinensis clone CMXR-GP4 unknown mRNA } \\
\text { (up regulated) }\end{array}$ & EU309047 & $100 \%$ & \\
\hline DEG 4 & $\begin{array}{c}\text { Influenza A virus (A/open-billed Stork/Nakhonsawan/ } \\
\text { BBA0627May/05(H5N1)) polymerase PA (PA) gene, } \\
\text { complete cds (up regulated) }\end{array}$ & EF112270 & $99 \%$ & $\begin{array}{c}\text { Subunit of the trimeric complex of the RNA-dependent- } \\
\text { RNA polymerase of Influenza A, involved in transcription } \\
\text { of viral RNAs }\end{array}$ \\
\hline DEG 5 & $\begin{array}{c}\text { Clonorchis sinensis clone ACP-1U-117-2 (down } \\
\text { regulated) }\end{array}$ & EU780119 & $100 \%$ & \\
\hline DEG 6 & $\begin{array}{c}\text { Tigriopus japonicus mitochondrial heat shock protein } \\
60 \text { (Hsp60) mRNA, complete cds; nuclear gene for } \\
\text { mitochondrial product (up regulated) }\end{array}$ & EU306562 & $99 \%$ & $\begin{array}{c}\text { Mitochondrial chaperonin that is typically held } \\
\text { responsible for the transportation and refolding of } \\
\text { proteins from the cytoplasm into the mitochondrial } \\
\text { matrix. Involved in stress response from cells, especially } \\
\text { during infection. }\end{array}$ \\
\hline DEG 7 & $\begin{array}{l}\text { PREDICTED: Gallus gallus hypothetical LOC418666 } \\
\text { (LOC418666), mRNA (up regulated) }\end{array}$ & XM416862 & $94 \%$ & \\
\hline DEG 8 & $\begin{array}{l}\text { PREDICTED: Gallus gallus hypothetical LOC426258 } \\
\text { (LOC426258), mRNA (down regulated) }\end{array}$ & XM423923 & $100 \%$ & \\
\hline DEG 9 & Unknown sequence (down regulated) & & & \\
\hline DEG 10 & Unknown sequence (down regulated) & & & \\
\hline DEG 11 & $\begin{array}{c}\text { Sus scrofa calcium transporter } 1 \text { (TRPV6) mRNA, partial } \\
\text { cds (down regulated) }\end{array}$ & FJ268731 & $100 \%$ & $\begin{array}{c}\text { Membrane calcium channel which regulates calcium } \\
\text { entry into the cell and also plays a role in calcium } \\
\text { reabsorption. }\end{array}$ \\
\hline
\end{tabular}

regulated were isolated and identified where 8 of them were unknown genes. For all the 3 host systems although the same 20 ACPs were used for amplification, not one of the proteins isolated in any one cell/host system is similar.

Overall, our studies have demonstrated that the responses of the three host systems to infections with the same virus were substantially different from each other. The functional roles, sequence similarities and characterization of differentially expressed transcripts are summarized in Table 3, 4 and 5. In this study, ACPbased RT-PCR results showed that most of the differentially expressed genes exhibited significantly higher sequence similarity (90 to100\%) with known coding regions of genes. Munir et al., 2005 have showed that the regulation of host cell transcription following infection with a virus is an intricate phenomenon and may or may not be shared among viral agents; indicating that viruses that are evolutionarily closely related may not share similar mechanisms to regulate host gene expression and likely have their own signature patterns of altering host physiology during replication. In our study, we can also conclude that host cell responses or the regulation of host cell transcriptions of different permissible cell or host systems following infection with the same virus may have their own specific patterns for altering host gene expressions and may not share similar mechanisms and pathways.

One of the drawbacks in using this technique is the small number of DEGs generated that could be captured on agarose gels. In comparison to the large numbers of expressed genes that can be investigated using nucleic acid microarrays. Despite this, we found several interesting genes, which were predominantly and consistently up regulated only in infected cells both in cell lines and also lung tissues. They are the Hsp60 small heat shock proteins, Cyclin D2, Interleukin-8.

Hsp60 is a common cellular protein that assists in the correct folding of proteins and stabilizes unfolded labile proteins [24]. These functions maintain the activities of some cellular proteins and facilitate enzymatic maturation. The former is a well-known function of Hsp60 under stress conditions, and an example of the latter is activation of procaspase- 3 and prion protein through conformational change by Hsp60 [25-27]. Functioning as a chaperonin in eukaryotes, Hsp60 assembles into a heptamer and has ATPase activity for the release of bound protein $[25,28]$. Hsp60 is an essential factor for 
Table 4 Sequence similarities and characterization of of Madine Darby Canine Kidney Cells (MDCK)

\begin{tabular}{|c|c|c|c|c|}
\hline $\begin{array}{l}\text { Clone } \\
\text { Name }\end{array}$ & Identity & $\begin{array}{l}\text { Accession } \\
\text { Number }\end{array}$ & $\begin{array}{l}\text { Homology } \\
\text { (\%) }\end{array}$ & Putative functional role \\
\hline DEG 12 & $\begin{array}{l}\text { Gibberella moniliformis p450-4 gene for ent-kaurene } \\
\text { oxidase, exons 1-4, strain A-00149 (up regulated) }\end{array}$ & AM946177 & $100 \%$ & Responsible for the synthesis of plant terpenoids. \\
\hline DEG 13 & $\begin{array}{c}\text { Pongo abelii reticulon } 4 \text { (RTN4), mRNA >emb| } \\
\text { CR861110.1| Pongo abelii mRNA; CDNA } \\
\text { DKFZp459C0314 (from clone DKFZp459C0314) (down } \\
\text { regulated) }\end{array}$ & NM001133403 & $90 \%$ & $\begin{array}{c}\text { Protein that in humans is encoded by the RTN } 4 \text { gene } \\
\text { that has been identified as an inhibitor of neurite } \\
\text { outgrowth specific to the central nervous system. It is } \\
\text { also known to interact with Bcl-2 gene which is } \\
\text { involved in promoting and inhibiting apoptosis in } \\
\text { cells during stress. }\end{array}$ \\
\hline DEG 14 & $\begin{array}{c}\text { Homo sapiens amyloid beta (A4) precursor protein, } \\
\text { mRNA (cDNA clone IMAGE:4126584), (down } \\
\text { regulated) }\end{array}$ & BC018937 & $94 \%$ & $\begin{array}{c}\text { Neuronal adaptor protein that interacts with the } \\
\text { Alzheimer's disease amyloid precursor protein (APP). It } \\
\text { stabilizes APP and inhibits production of proteolytic } \\
\text { APP fragments including the A beta peptide that is } \\
\text { deposited in the brains of Alzheimer's disease } \\
\text { patients }\end{array}$ \\
\hline DEG 15 & $\begin{array}{c}\text { Influenza A virus (A/open-billed stork/Nakhonsawan/ } \\
\text { BBA0627 May/05(H5N1)) polymerase PA (PA) gene, } \\
\text { complete cds (up regulated) }\end{array}$ & EF112270 & $99 \%$ & $\begin{array}{l}\text { Subunit of the trimeric complex of the RN } \\
\text { polymerase of Influenza A, involved in tra RNAs }\end{array}$ \\
\hline DEG 16 & unknown gene (down regulated) & & & \\
\hline DEG 17 & $\begin{array}{c}\text { PREDICTED: Canis familiaris similar to ribosomal } \\
\text { protein L14, transcript variant } 2 \text { (LOC480789), mRNA } \\
\text { (down regulated) }\end{array}$ & XM537906 & $100 \%$ & $\begin{array}{c}\text { Encodes a ribosomal protein that is a compon } \\
\text { Involved in transcription }\end{array}$ \\
\hline DEG 18 & $\begin{array}{c}\text { Tigriopus japonicus mitochondrial heat shock protein } \\
60 \text { (Hsp60) mRNA, complete cds; nuclear gene for } \\
\text { mitochondrial product (up regulated) }\end{array}$ & EU306562 & $100 \%$ & $\begin{array}{c}\text { Mitochondrial chaperonin that is typically } \\
\text { transportation and refolding of proteins fr } \\
\text { mitochondrial matrix. Involved in stre especially } \\
\text { during infection. }\end{array}$ \\
\hline DEG 19 & $\begin{array}{c}\text { TPA: TPA_inf: Canis familiaris RTN4-CW (RTN4) gene, 3' } \\
\text { UTR (up regulated) }\end{array}$ & BK003960 & $99 \%$ & Inhibitor of neurite outgrowth specific to t system. \\
\hline DEG 20 & $\begin{array}{l}\text { PREDICTED: Equus caballus similar to cyclin D2 } \\
\text { (LOC100051150), mRNA (down regulated) }\end{array}$ & XM001494152 & $94 \%$ & $\begin{array}{l}\text { Belongs to the highly conserved cyclin family, whose } \\
\text { members are characterized by a dramatic periodicity } \\
\text { in protein abundance through the cell cycle. Cyclins } \\
\text { function as regulators of cyclin-dependent kinases. } \\
\text { Forms a complex with and functions as a regulatory } \\
\text { subunit of CDK4 or CDK6, whose activity is required } \\
\text { for cell cycle G1/S transition. Involved in the } \\
\text { phosphorylation of tumor suppressor protein Rb }\end{array}$ \\
\hline DEG 21 & $\begin{array}{l}\text { Mouse mRNA for amyloid beta precursor (protease } \\
\text { nexin II) (up regulated) }\end{array}$ & X59379 & $95 \%$ & $\begin{array}{c}\text { Up regulated during neuronal differentiati neural } \\
\text { injury. }\end{array}$ \\
\hline DEG 22 & unknown gene (down regulated) & & & \\
\hline DEG 23 & $\begin{array}{c}\text { Bos taurus reticulon } 4 \text { (RTN4), transcript variant 1, } \\
\text { mRNA }>\text { gb|AY164744.2| Bos taurus RTN4-C (RTN4) } \\
\text { mRNA, complete cds (up regulated) }\end{array}$ & NM001075138 & $88 \%$ & $\begin{array}{c}\text { Inhibitor of neurite outgrowth specific to the central } \\
\text { nervous system }\end{array}$ \\
\hline
\end{tabular}

the activation of human Hepatitis B Virus polymerase for it to function inside cellular environment [29]. Apart from that, Hsp60 as a mitochondrial protein has been shown to be involved in stress response as well. The heat shock response is a homeostatic mechanism that that protects cell from damage by up regulating the expression of genes that code for Hsp60 [30]. The up regulation of Hsp60 production allows for the maintenance of other cellular processes occurring in the cell, especially during stressful times. Infection and disease are extremely stressful on the cell. When a cell is under stress, it naturally increases the production of stress proteins, including heat shock proteins such as Hsp60. In order for Hsp60 to act as a signal it must be present in the extracellular environment. This explains the up regulated various types of heat shock protein and Interleukin-8 cytokine which we found during time of infection in our study. In addition to that, IL-8 is also a potent chemo-attractant and stimulus of neutrophils. It plays a pivotal role in inflammatory diseases. Hsp60 has also been found to be involved in signal transduction cascade of immune response when the cells are under stress from environment, in this case under viral attack. It acts as a signaling molecule, and indicates the action for other immune molecules such as cytokines (interleukins, interferons and also tumor necrosis factor) [31-34]. Further investigation on this Hsp60 also is essential, especially as it may shed some light on its role in cytokine storm that occurs in most H5N1 infection which is fatal to the host. 
Table 5 Sequence similarities and characterization of differentially expressed transcripts of Chicken Lung Tissues

\begin{tabular}{|c|c|c|c|c|}
\hline $\begin{array}{l}\text { Clone } \\
\text { Name }\end{array}$ & Identity & $\begin{array}{l}\text { Accession } \\
\text { Number }\end{array}$ & $\begin{array}{l}\text { Homology } \\
(\%)\end{array}$ & Putative functional role \\
\hline DEG 24 & $\begin{array}{c}\text { Influenza A virus (A/open-billed stork/Nakhonsawan/ } \\
\text { BBA0627 May/05(H5N1)) polymerase PA (PA) gene, } \\
\text { complete cds (up regulated) }\end{array}$ & EF112270 & $99 \%$ & $\begin{array}{l}\text { Subunit of the trimeric complex of RNA polymerase of } \\
\text { Influenza transcription of viral RNAs. }\end{array}$ \\
\hline DEG 25 & $\begin{array}{l}\text { Messenger fragment for chicken pro-alpha-1 (I) collagen } \\
\text { (up regulated) }\end{array}$ & V00401 & $96 \%$ & $\begin{array}{l}\text { Encodes the major component of type I collagen, the } \\
\text { fibrillar collagen found in most connective tissues, } \\
\text { including cartilage, involved in cell proliferation. }\end{array}$ \\
\hline DEG 26 & $\begin{array}{c}\text { Gallus gallus mRNA for hypothetical protein, clone } 6118 \\
\text { (down regulated) }\end{array}$ & AJ719809 & $97 \%$ & \\
\hline DEG 27 & $\begin{array}{c}\text { Synthetic construct immunoglobulin heavy chain mu } \\
\text { constant region and immunoglobulin heavy chain } \\
\text { gamma } 1 \text { constant region genes, partial cds (down } \\
\text { regulated) }\end{array}$ & EF495199 & $99 \%$ & $\begin{array}{l}\text { Have variable domains which are important for } \\
\text { binding with antigens. }\end{array}$ \\
\hline DEG 28 & $\begin{array}{c}\text { Clonorchis sinensis clone CMXR-GP77 pyruvate } \\
\text { dehydrogenase a-chain type } 1 \text { mRNA, partial cds (down } \\
\text { regulated) }\end{array}$ & EU290665 & $100 \%$ & $\begin{array}{c}\text { First component enzyme of pyruvate dehydrogenase } \\
\text { complex, contributes to transforming pyruvate into } \\
\text { acetyl-CoA by a process called pyruvate } \\
\text { decarboxylation in citric acid cycle (cellular respiration). }\end{array}$ \\
\hline
\end{tabular}

$\begin{array}{ll}\text { DEG } 29 & \text { unknown gene (down regulated) } \\ \text { DEG } 30 & \text { unknown gene (down regulated) } \\ \text { DEG } 31 & \text { unknown gene (down regulated) } \\ \text { DEG } 32 & \text { unknown gene (down regulated) }\end{array}$

DEG 33 Sus scrofa calcium Transporter 1 (TRPV6) mRNA, partial FJ268731 cds (down regulated)

DEG $34 \quad$ PREDICTED. Gallus gallus hypothetical LOC418666 XM416862 (LOC418666), mRNA (up regulated)

DEG 35 Rattus norvegicus phosphodiesterase 7A (Pde7a), mRNA NM031080 (down regulated)

DEG 36 Marmota monax interleukin 8 (IL-8) gene, complete cds EU332349 (up regulated)
Membrane calcium channel which regulates calcium entry into the cell and also plays a role in calcium reabsorption.

DEG 37 Crassostrea gigas catalase mRNA, complete cds (down EF687775 regulated)

$94 \%$

$90 \%$

$100 \%$

Chemokine produced by macrophages and other cell types such as epithelial cells. It is one of the major mediators of the inflammatory response, particularly, serves as a chemical signal that attracts neutrophils at the site of inflammation.
We also found the cyclin D2 transcript down regulated only during time of infection in MDCK cell lines which mimics a mammalian model of study. This cyclin forms a complex with and functions as a regulatory subunit of CDK4 or CDK6, whose activity is required for cell cycle G1/S transition. This protein has been shown to interact with and be involved in the phosphorylation of tumor suppressor protein Rb. G1 cell cycle regulators are often targets for deregulation in cancers $[35,36]$. Cyclin D2 is up regulated in many cancers, including breast cancer and its role is to increase cellular proliferation. In addition to cancer, the cyclin Ds are often seen deregulated in viral infections. For instance, cyclin D2 is up regulated in Epstein-Barr virus (EBV) and Hepatitis B virus (HBV) infected cells $[37,38]$ and cyclin D1 is up regulated in Simian virus 40 (SV40) transformed cells [39]. It is interesting to note that EBV and $\mathrm{HBV}$, both of which have increase levels, are associated with cancers. Many oncogenic viruses contain a viral protein, such as the SV40 $\mathrm{T}$ antigen and human papillomavirus (HPV) E6 and E7 proteins, which aid intumorigenesis by altering cell cycle progression $[40,41]$. Interestingly, in our study, we have found that, all 3 of the Cyclins, D1, D2 and D3 were down regulated. Very little is known about crosstalks between influenza A virus and the cellular machineries that regulate the cell cycle, thus our finding clearly opens up new avenues of research to determine whether alteration of cell cycle progression is a strategy used by $\mathrm{H} 5 \mathrm{~N} 1$ Avian Influenza virus to better replicate in host cells.

\section{Conclusion}

The use of functional genomics methods, led by mRNA differential display technique, has significantly advanced our findings of organ and cell specific transcriptomes, especially when comparisons are made between infected and non-infected. We have managed to identify and isolate 37 authentic genes which were up and down regulated in this study. These findings in this preliminary study with MDCK and CeLu cell lines and lung tissues 


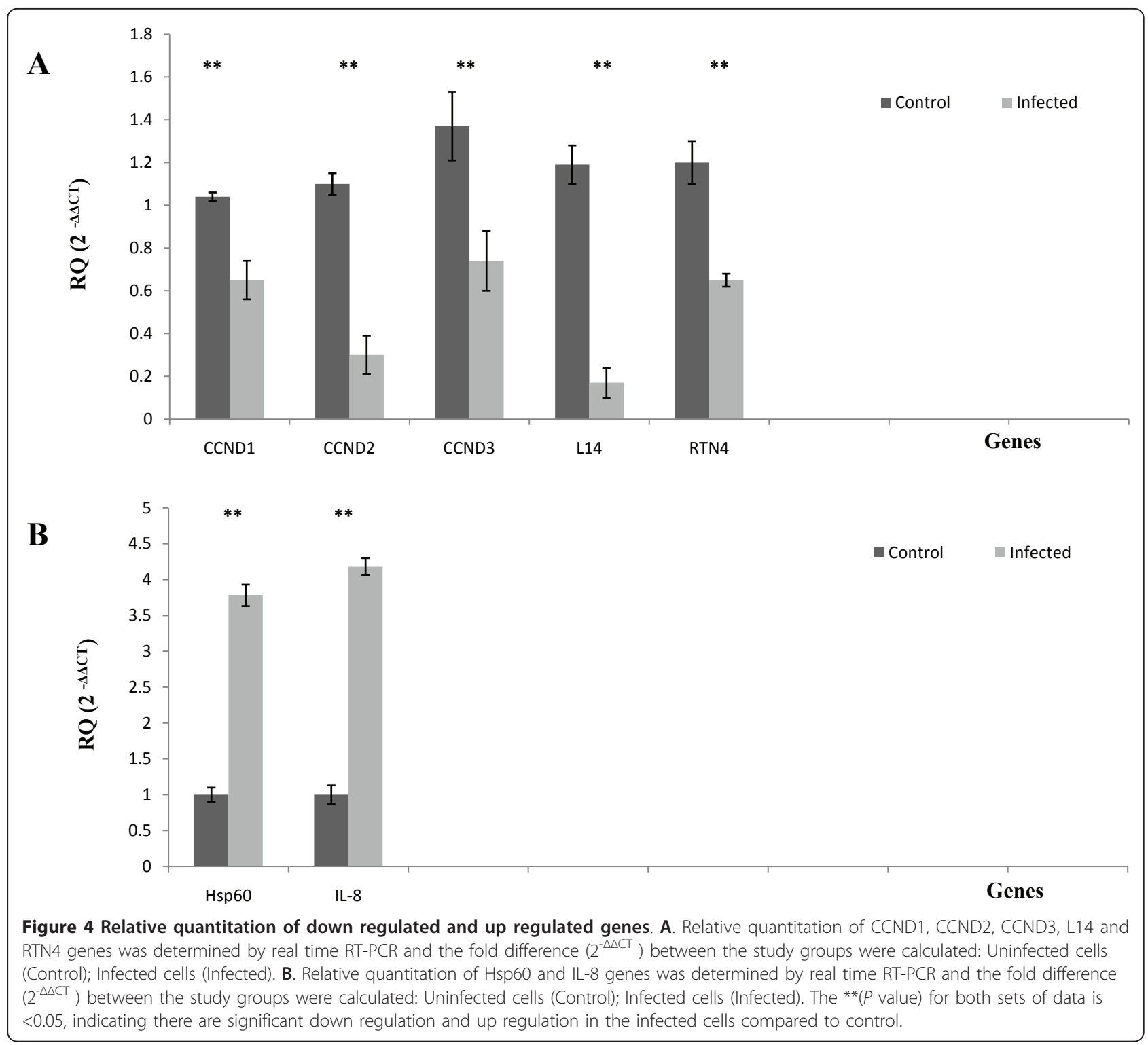

has open up new avenues of research especially into exploration and elucidating the functions of several interesting candidate genes such as the Hsp60, cyclin D2, IL-8 and the many unknown genes, and elucidating any role they might play in the virulence or pathogenicity of the virus. We have also shown that host systems infected by the same virus may have their own specific patterns for altering host gene expressions and may not share similar mechanisms and pathways. With further identification of these novel genes and the availability of sequence data of some of the unknown genes, would provide resources for further research in their use as markers or inhibitors in the development of novel biologics and reagents for diagnostic and anti-viral therapies.

\section{List of Abbreviations}

MDCK: Madin Darby Canine Kidney; CeLu: Chicken Embryo Lung; HPAl: Highly Pathogenic Avian Influenza; AIV: Avian Influenza Virus; ACP: Annealing Control Primer; TCID: Tissue Culture Infective Dose; EID: Egg Infective Dose; DEGs: Differentially Expressed Genes; Hsp60: Heat Shock Protein 60, CDK4: Cyclin Dependant Kinase 4; CDK6: Cyclin Dependant Kinase 6; EBV: Epstein Barr virus; HBV: Hepatitis B Virus; HPV: Human Papillomavirus; CCND1: Cyclin D1; CCND2: Cyclin D2; CCND3: Cyclin D3; RTN4: reticulon 4; L14: ribosomal protein L14; IL8: Interleukin 8.

\section{Acknowledgements}

We thank Leo Poon (Hong Kong University) for his valuable advice. We also thank Prof. Dato' Anuar Zaini, Head of Jeffrey Cheah School of Medicine and Health Sciences for his support in this project. This research was supported by internal grant MED2009-INI (MG)-001-SH from Monash University.

\section{Author details}

'Infectious Disease Laboratory (MR3), School of Medicine and Health Sciences, Monash University, Sunway Campus, Kuala Lumpur, Malaysia. 
${ }^{2}$ Institute of Bioscience, University Putra Malaysia, UPM Serdang, Selangor, 43400, Malaysia. ${ }^{3}$ Veterinary Research Institute, 31400 Ipoh, Perak, Malaysia.

\section{Authors' contributions}

SSH conceived of the study. SSH, ARO, MM, SMN, RM and $1 \mathrm{O}$ discussed the results. VRMTB and SSH performed the experiments, and VRMTB prepared the manuscript.

All authors have read and approved the final manuscript.

\section{Authors' information}

1. Assoc.Prof.Dr.Sharifah Syed Hassan (SSH)

Associate Professor - Microbiology

Doctor of Veterinary Medicine, UPM, Malaysia, 1983

MSc in Veterinary Microbiology, Univ. Surrey, UK, 1990

D. Phil Univ. of Oxford, UK, 1999

Dr.Sharifah joined Monash University, Sunway campus, Malaysia in March 2008 as an Associate Professor in Microbiology. She was the Director of Veterinary Research Institute (VRI), Malaysia from 2004 to 2007. She had extensive exposure and research experiences in areas of animal viral vaccine production, avian and mammalian virology diagnostics and research. Her main focuses of research are in production of recombinant proteins, viral and gene discovery for the development of novel diagnostic reagents and antiviral therapy. Her current work and research interests are in areas of cellular gene expression of virus infected cells especially Nipah and Avian Influenza Viruses.

2. Vinod RMT Balasubramaniam (VRMTB) finished his undergraduate degree in Asian Institute of Medicine, Science and Technology in 2007, majoring in Biotechnology. There, he produced several papers on plant genetic engineering, especially on genetically engineered orchids which have resistant towards fungus. He was accepted as research assistant under SSH in her laboratory. Subsequently, he was accepted to do PhD under SSH and currently undertaking the project, specially emphasizing on various host cellular genes infected with Avian Influenza Virus and their protein-protein interaction with viral genes.

\section{Competing interests}

The authors declare that they have no competing interests.

Received: 21 October 2010 Accepted: 29 April 2011

Published: 29 April 2011

\section{References}

1. Zurcher T, Marion RM, Ortin J: Protein synthesis shut-off induced by Influenza virus infection is independent of PKR activity. J Virol 2000 74:8781-8784.

2. Katze MG, Krug RM: Translational control in influenza virus infected cells. Enzyme 1990, 44:265-277.

3. Garfinkel MS, Katze MG: Translational control by influenza virus. Selective and cap-dependent translation of viral mRNAs in infected cells. J Biol Chem 1992, 267:9383-9390.

4. Schroder M, Kaufman RJ: The mammalian unfolded protein response. Annu Rev Biochem 2005, 74:739-789.

5. Holcik M, Sonenberg N: Translational control in stress and apoptosis. Nat Rev Mol Cell Biol 2005, 6:318-327.

6. Clemens MJ: Translational control in virus-infected cells: models for cellular stress responses. Semin Cell Dev Biol 2005, 16:13-20.

7. Hien TT, Jong de M, Farrar J: Avian influenza - A challenge to global health care structures. N Engl J Med 2004, 351:2363-2365.

8. Quirk M: Zoo tigers succumb to avian influenza. Lancet Infect Dis 2004, $4: 716$

9. Thanawongnuwech $\mathrm{R}$, Amonsin A, Tantilertcharoen $\mathrm{R}$, Damrongwatanapokin S, Theamboonlers A, Payungporn S, et al: Probable tiger-to-tiger transmission of avian influenza H5N1. Emerg Infect Dis 2005, 11:699-701.

10. Thornley M: Avian influenza ravages Thai tigers. Aust Vet J 2004, 82:652.

11. Munir S, Kapur V: Transcriptional analysis of the response of poultry species to respiratory pathogens. Poultry Science 2003, 82:885-892.

12. Karpala AJ, Lowenthal JW, Bean AG: Activation of the TLR3 pathway regulates IFNb production in chickens. Dev Comp Immunol 2008, 32:435-444.
13. Xing Z, Cardona CJ, Li J, Dao N, Tran T, Andrada J: Modulation of the immune responses in chickens by low-pathogenicity avian influenza virus H9N2. J Gen Virol 2008, 89:1288-1299.

14. Hogenkamp A, Isohadouten N, Reemers SS, Romijn RA, Hemrika W, White MR, et al: Chicken lung lectin is a functional C-type lectin and inhibits haemagglutination by influenza A virus. Vet Microbiol 2008, 130:37-46.

15. Reading PC, Bozza S, Gilbertson B, Tate M, Moretti S, Job ER, et al: Antiviral activity of the long chain pentraxin PTX3 against Influenza viruses. J Immunol 2008, 180:3391-3398.

16. Hwang IT, Kim YJ, Kim SH, Kwak Cl, Gu YY, Chun JY: Annealing control primer system for improving specificity of PCR amplification. Biotechniques 2003, 35:1180-4.

17. Kim YJ, Kwak Cl, Gu YY, Hwang IT, Chun JY: Annealing control primer system for identification of differentially expressed genes on agarose gels. Biotechniques 2004, 36:424-30.

18. Altschul SF, Gish W, Miller W, Myers EW, Lipman DJ: Basic local alignment search tool. J Mol Biol 1990, 215:403-10.

19. Schmittgen TD, Livak KJ: Analyzing real-time PCR data by the comparative C(T) method. Nat Protoc 2008, 3:1101-1108.

20. Wan JS, Sharp SJ, Poirier GM, Wagaman PC, Chambers J, Pyati J, Hom YL, Galindo JE, Huvar A, Peterson PA, Jackson MR, Erlander MG: Cloning differentially expressed mRNAs. Nat Biotechnol 1996, 14:1685-91.

21. Welss T, Papoutsaki M, Michel G, et al: Molecular basis of basal cell carcinoma: Analysis of differential gene expression by differential display PCR and expression array. Int J Cancer 2003, 104:66-72.

22. Shalon D: Gene expression micro-arrays: a new tool for genomic research. Pathol Biol 1998, 46:107-9.

23. Kihara C, Tsunoda T, Tanaka T, et al: Prediction of sensitivity of esophageal tumors to adjuvant chemotherapy by cDNA microarray analysis of gene expression profiles. Cancer Res 2001, 61:6474-6479.

24. Bukau B, Horwich AL: The Hsp70 and Hsp60 chaperone machines. Cell 1998, 92:351-366.

25. Edenhofer F, Rieger R, Famulok M, Wendler W, Weiss S, Winnacker EL: Prion protein PrPc interacts with molecular chaperones of the Hsp60 family. J Virol 1999, 70:4724-4728.

26. Samali A, J Cai, Zhivotovsky B, Jones DP, Orrenius S: Presence of a preapoptotic complex of pro-caspase-3, Hsp60 and Hsp10 in the mitochondrial fraction of jurkat cells. EMBO J 1999, 18:2040-2048.

27. Xanthoudakis S, S Roy, Rasper D, Hennessey T, Aubin Y, Cassady R, et al: Hsp60 accelerates the maturation of pro-caspase-3 by upstream activator proteases during apoptosis. EMBO J 1999, 18:2049-2056.

28. Todd MJ, Viitanen PV, Lorimer GH: Dynamics of the chaperonin ATPase cycle: implications for facilitated protein folding. Science 1994, 265:659-666.

29. Sung GP, Guhung J: Human Hepatitis B Virus Polymerase Interacts with the Molecular Chaperonin Hsp60. J Virol 2001, 75:6962-6968.

30. Vargas-Parada L, Solis C: "Heat Shock and stress response of Taenia solium and T. crassiceps". Parasitology 2001, 211:583-8.

31. Ranford JC, Coates AR, Henderson B: "Chaperonins are cell-signalling proteins: the unfolding biology of molecular chaperones". Expert Rev Mol Med 2000, 2:1-17.

32. Hansen JJ, Bross P, Westergaard M, Nielsen MN, Eiberg H, Børglum AD, et al: The genomic structure of the human mitochondrial chaperonin genes: HSP60 and HSP10 are localized head to head on chromosome 2 separated by a bidirectional promoter. Hum Genet 2003, 112:71-77.

33. Zhao Q, Wang J, Levichkin IV, Stasinopoulos S, Ryan MT, Hoogenraad NJ: A mitochondrial specific stress response in mammalian cells. EMBO J 2002, 21:4411-4419.

34. Pochon NAM, Mach B: Genetic complexity of the human hsp 60 gene. Int Immunol 1996, 8:221-230.

35. Aaltomaa S, Lipponen P, Ala-Opas M, Eskelinen M, Syrjanen K, Kosma VM: Expression of cyclins $A$ and $D$ and $p 21$ (waf1/cip1) proteins in renal cell cancer and their relation to clinicopathological variables and patient survival. Br J Cancer 1999, 80:2001-2007.

36. Balasubramanian S, Ahmad N, Jeedigunta S, Mukhtar H: Alterations in cell cycle regulation in mouse skin tumors. Biochem Biophys Res Commun 1998, 243:744-748

37. Spender LC, Cornish GH, Rowland B, Kempkes B, Farrell PJ: Direct and indirect regulation of cytokine and cell cycle proteins by EBNA-2 during Epstein-Barr virus infection. J Virol 2001, 75:3537-3546. 
38. Cannell EJ, Farrell PJ, Sinclair AJ: Epstein-Barr virus exploits the normal cell pathway to regulate $\mathrm{Rb}$ activity during the immortalization of primary Bcells. Oncogene 1996, 13:1413-1421.

39. Watanabe G, Howe A, Lee RJ, Albanese C, Shu IW, Karnezis AN, et al: Induction of cyclin D1 by simian virus 40 small tumor antigen. Proc Natl Acad Sci USA 1996, 93:12861-12866.

40. Rapicetta M, Ferrari C, Levrero M: Viral determinants and host immune responses in the pathogenesis of HBV infection. J Med Virol 2002, 67:454-457.

41. Hirai H, Roussel MF, Kato JY, Ashmun RA, Sherr CJ: Novel INK4 proteins, p19 and p18, are specific inhibitors of the cyclin D dependent kinases CDK4 and CDK6. Mol Cell Biol 1995, 15:2672-2681.

doi:10.1186/1743-422X-8-196

Cite this article as: Balasubramaniam et al.: Cellular transcripts regulated during infections with Highly Pathogenic H5N1 Avian Influenza virus in 3 host systems. Virology Journal 2011 8:196.

\section{Submit your next manuscript to BioMed Central} and take full advantage of:

- Convenient online submission

- Thorough peer review

- No space constraints or color figure charges

- Immediate publication on acceptance

- Inclusion in PubMed, CAS, Scopus and Google Scholar

- Research which is freely available for redistribution

Submit your manuscript at www.biomedcentral.com/submit 